\title{
MANAJEMEN RISIKO PADA BANK PEMBANGUNAN DAERAH JAWA BARAT DAN BANTEN TbK
}

\author{
Lutfi Alif Tiyani', Diah Febriyanti², Siti Ummi Munawaroh³, Ulin Ni'mah ${ }^{4}$ \\ Corresponding Author's: Institut Agama Islam Negeri Kudus \\ Email : unaputrimunawaroh@gmail.com \\ Copyright (C) 2021

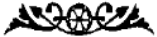

\begin{abstract}
This study aims to identify and analyze risk management in banking, namely risk, operational risk, market risk, liquidity risk, legal risk, compliance risk, yield risk and investment risk. And to analyze the financial ratio reports for the first quarter and second quarter of 2020 at the West Java and Banten (BJB) Tbk development bank. This research uses descriptive quantitative method at PT. West Java and Banten Regional Development Bank Tbk (BJB) Tbk which are listed on the Indonesia Stock Exchange during the period 2018 to 2020. The sample in this study is PT. West Java Regional Development Bank and Banten Tbk (BJB) which are registered on the IDX and are still operating in the 20182020 period. Data collection tools in this study are to use the method of observation on financial data at the bank and internet research. The results of this study indicate the existence of smooth and bad conditions in management analysis and financial ratio analysis at BJB banks which consist of analysis of CAR, non-performing assets, CKPN, gross NPF, NPF Net, ROA, ROE, NI, NOM, $B O P O$, and FDR. The results of the overall calculation at PT. West Java Regional Development Bank and Banten Tbk, in the 2018-2020 period experienced an increase and decrease every year
\end{abstract}

Keywords: Risk management, CAR, NPF, ROA, NOM, BOPO.

\section{PENDAHULUAN}

Bank merupakan salah satu bidang usaha yang menarik. Di Indonesia sendiri perusahaan perbankan menjadi salah satu perusahaan yang paling diminati oleh masyarakat diIndonesia. Bank adalah suatu lembaga keuangan yang memiliki peran dan juga fungsi yang sangat penting dalam perekonomian manusia. Bank adalah suatu badan usaha yang berfungsi menghimpun dana dari masyarkat (dana pihak ketiga) dalam bentuk simpanan berupa tabungan, giro dan deposito dan menyalurkanya dalam bentuk kredit atau lainnya (UU Nomor 10 tahun 1998). Di Indonesia sendiri bank banyak sekali jenisnya yakni salah satunya yaitu bank pembangunan daerah (BPD).

Bank pembangunan daerah di Indonesia banyak sekali salah satunya Bank Pembangunan daerah Jawa Barat dan Banten Tbk (BJB). Dimana bank 
tersebut menjadi objek pada penelitian ini. BJB adalah salah satu bank BUMD milik pemerintah provinsi jawabarat dan banten. Penelitian ini merujuk pada BJB yang pada kebanyakan penelitian terdahulu itu melakukan penelitian pada bank umum lainnya. BJB itu sendiri sebenarnya termasuk bank yang sudah terdaftar dalam bursa efek Indonesia.

Seperti yang kita lihat partumbuhan ekonomi perbankan dari tahun ke tahun semakin cepat begitu juga pada bank BJB. Dimana pertumbuhan kredit BJB sendiri sudah mencapai 8,68 $\%$ pada tahun 2019. Bukan hanya pertumbuhan kredit tapi juga income meningkat $1,42 \%$, year profit meningkat $0,78 \%$ dengan total asset mencapai $2,73 \%$. Equity juga meningkat 6,71\% dan dana pihak ketiga juga meningkat 2,13\%. Tapi noan perfoming loan mengalami penurunan 0,81\% pada tahun 2019 kemarin.

BJB termasuk bank yang memilki tingkat kredit yang tinggi karena itu manajemen harus bisa memperhatikan tingkat risiko, tingkat kehati hatian yang mungkin akan tejadi pada pertumbuhan bank tersebut. Oleh karena itu penting bagi manajemen risko atau manajemen risiko dari bank BJB untuk mengukur potensi kemungkinanan terjadinya tingkat risiko pada bank tersebut. BJB sendiri memiliki banyak layanan kredit pada tahun 2019 tercatat ada 5 layanan kredit yakni kredit guna bakti, kredit koperas karyawan, kredit modal kerja kontuksi, kredit modal kerja umum pertumbuan dan simpanan. Karena banyaknya layanan kredit yang di berikan maka kemungkinan tingkat risiko juga ada baik dari dalam perusahaan maupun luar perusahaan.Bukan hanya kredit tapi juga BJB perlu menganalisis adanya risiko pada likuiditas, operasional, hukum, reptasi, strategic, imbal hasil dan juga terkait investasi.Dari pembahasan tersebut maka kami melakukan penelitian tentang analisis manajemen risiko yang terjadi pada bank pembangunan daerah jabar dan banten (BJB).

\section{KAJIAN TEORI}

\section{Manajemen Risiko}

Risiko dalam konteks ekonomi adalah kerugian yang terjadi pada suatu peristiwa atau event.Sedangkan dalam dunia perbankan sendiri risiko memiliki arti suatu kejadian atau peristiwa potensial di mana risiko tersebut bisa di perkirakan maupun yang tidak bisa diperkirakan yang berdampak buruk terhadap bank baik itu bisa mempengaruhi modal ataupun pendapatan. Maka dari itu risiko dianggap sebagai hambatan dalam mencapai tujuan (surat edaran BI no.13 tahun 2011). Bank sendiri memiliki pertumbuhan yang sangat pesat tiap tahunnya karena itu agar terhindar dari yang namanya risiko bank memerlukan sebuah manajemen risiko untuk memprediksi terjadinya risiko agar dapat meminimalisir kerugian yang didapat oleh bank.

Manajemen risiko merupakan aktivitas yang paling utama yang di miliki sebuah bank untuk mengopti- 
malkan trade off dari risiko dan pendapatan (income). Jadi manajemen risiko itu tersebut. Maka dari itu manajemen risiko memiliki 8 jenis risiko yang wajib di kelola dan di pertimbangkan oleh suatu bank umum.

\section{Risiko Kredit}

Risiko kredit pada bank merupakan risiko yang terjadi akibat gagal bayar pada nasabah dalam memenuhi kewajiban pada bank, pada hal ini termasuk risiko kredit yang terjadi akibat gagal bayar dari debitur, risiko konsentrasi pada suatu kredit, counterparty credit risk, dan settlement risk (OJK no. 18/POJK.03/2016).Risiko kredit adalah kerugian yang di derita olehbank itu sendiri yaitu biasannya terkait dengan apabila sudah jatuh tempo counterparty atau pihak lawan gagal dalam memenuhi kewajibanya pada bank.

Kredit bermasalah pada perbankan disebut non performing loan (NPL). Dengan ketentuan yakni pada kualitas kredit, yang terbagi atas kredit Lancar (KL), Kredit Dalam Perhatian Khusus (DPK). Kredit Kurang Lancar (KL), Kredit Diragukan (D), dan Kredit Macet (M). BI menetapkan rasio kredit bermasalah adalah tidak boleh melebihi 5\%. Rumus NPL yakni:

\section{NPL= KREDIT BERMASALAH X 100\% KREDIT YANG DISALURKAN}

\section{Risiko Pasar}

Risiko pasar dalam perbankan adalah risiko yang terjadi apabila pada posisi neraca dan rekening administratif, termasuk transaksi derivative terjadi akibat perubahan secara menyeluruh dari kondisi pasar, termasuk risiko perubahan harga option (bank Indonesia). Sebagai contoh :

1. Suatu Bank membeli sukuk Negara dengan menggunakan kupon tetap, di mana nilai harga dari pasar obligasimengalami penurunan apabila jika imbal hasil pasar meningkat

2. Bank membeli USD (valas) dengan nilai dalam valuta rupiah akan menurun apabila nilai tukar USD melemah.

Risiko pasar pada perbankan bisa diukur dengan menggunakan Value at Risk (VaR) dimana probabilitas estimasi dari nilai kerugian portofolio berdasarkan pada analisis statistik yang terdapat pada trend harga historis dan volatilitas (Korna Risk Management, 2010)

\section{Risiko likuiditas}

Risiko liquiditas pada perbankan adalah risiko yang disebabkan ketidakmampuan bank dalam memenuhi ewajiban pada nasabah saat jatuh tempo dari sumber dana pada arus kas dan dari aset liquid yang berkualitas tinggi yangbisa digunakan, tanpa terjadi gangguan pada operasional keuangan. Penyebab terjadinya risiko liquiditas pada perbankan antara lain:

1. Pada bank terdapat adanya penurunan tingkat ketidak percayaan terhadap nasabah

2. Kebergantungan bank pada deposan 
dan Keterbatasan instrumen keuangan yang dimiliki oleh bank untuk solusi penanganan likuiditas.

\section{Risiko Operasional}

Risiko operasional adalah risiko yang terjadi pada perbankan akibat ketidakcukupan system operasioanal perbankan dan tidak berfungsinya proses internal perusahaan, kesalahan manusia (human error), kegagalan sistem, dan bisa diakibatkan karena kejadian eksternal yang mempengaruhi operasional bank. Sebagai contoh:

1. Pemalsuan bilyet deposito yang dilakukan oleh karyawan bank

2. Kesalahan postingan pada uang masuk dari nasabah

3. Sedangkan kejadian eksternal misalnya Terjadi bencana alam berupa banjir besar oleh karena itu bank tidak bisa beroperasi.

\section{Risiko Hukum}

Resiko hukum adalah Resiko yang terjadi disebabkan oleh adanya kelemahan aspek yuridis, sepertihalnya adanya tuntutan hukum pada perbankan. Contohnya Bank A tidak melakukan legal meeting pada saat memberikan kredit modal kerja kepada PT B, yakni pada verifikasi pengesahan Kementrian Hukum dan HAM atas perubahan Anggaran Dasar PT B. Di hari berikutnya, pengurus dari PT B telah melakukan pemalsuan pengesahan Anggaran Dasar PT B. akibatnya Bank A mengalami resiko hukum (Ikatan Bankir Indonesia: 345).

\section{Risiko Reputasi}

Risiko reputasi adalah yang terjadi akibat penurunan tingkat kepercayaan dari khalayak umum serta pemangku kepentingan (stakeholder) dari persepsi negatif pada bank. Reputasi ini terkait tindakan yang dilakukan oleh bank dan juga dari publikasi negative dari masyarakat terhadap bank. Misalnya sendiri jika suatu bank mengalami skimming (pembobolan pada mesin ATM) maka otomatis tingkat kepercayaan masyarakat menjadi turun dan akan membuat persepsi negative yang akan merusak reputasi suatu bank

\section{Risiko Strategik}

Risiko stategik Adalah risiko yang disebabkab oleh adanya penerapan dan pelaksanaa strategi pada bank yang tidak tepat, pegambilan keputusan bisnis yang dilakukan oleh bank juga tidak tepat atau bank tidak melaksanakan perubahan UU dan ketentuan lain yang berlaku.

Risiko strategic bersumber dari lemahnya proses perumusan sttrategi, yakni ketidaktepatan merumskan strategi bagi bank, system informasi manajemen yang tidak efektif, dan juga hasil analisi lingkungan baik intrnal maupun eksternal yang tidak memadai.

\section{Risiko Kepatuhan}

Risiko kepatuhan merupakan Risiko yang timbul karena bank tidak mematuhi ketentuan yang ada baik internal maupun eksternal pada suatu bank. Contohnya: 
1. Kententuan GWM yang ditetapkan oleh BI, Net Open Position, Non Performing Financing, dan Batas Maksimum Pemberian Pembiayaan.

2. Ketentuan dalam penyediaan produk

3. Ketentuan dalam pemberian pembiayaan atau kredit

4. Ketentuan dalam pelaporan baik laporan internal, laporan kepada Bank Indonesia maupun laporan kepada pihak ketiga lainnya

5. Ketentuan perpajakan.

\section{Risiko Imbal Hasil}

Risiko imbal hasil pada bank syariah adalah Risiko yang diakibatkan oleh perubahan tingkat imbal hasil pada bank yang dibayarkan kepada nasabah disebabkan adanya perubahan tingkat imbal hasil dari penyaluran dana yang diterima bank, yang akan memengaruhi perilakudari nasabah. Misalnya Bank memberikan imbal hasil yang lebih kecil dibandingkan dengan bulan lalu karena diakibatkan beberapa dari debiturnya mengalami penurunan kualitas pembiayaan.

Dalam manajemen resiko imbal hasil, bank syariah harus memiliki sistem yang tepat untuk mengidentifikasi dan pengukuran faktor faktor yang bisa meningkatkan resiko imbal hasil pada bank tersebut.

\section{Risiko Investasi}

Resiko Investasi adalah resiko akibat bank ikut menanggung kerugian usaha nasabah yang dibiayai dalam pembiayaan berbasis bagi hasil. Resiko ini timbul apabila bank memberikan pembiayaan berbasis bagi hasil kepada nasabah di mana bank ikut menanggung resiko atas kerugian nasabah yang dibiayai (profit and loss sharing). Resiko investasi memiliki beberapa fitur berbeda:

1. Sifat investasi ekuitas memerlukan pengawasan mendalam untuk mengurangi asimetri informasi

2. Mudhorobah dan musyarakah adalah perjanjian pembagian keuntungan dan kerugian serta menghadapi resiko hilangnya modal walau dengan pengawasan yang memadai. Tingkat resiko lebih tinggi dibandingkan investasi lain.

3. Investasi ekuitas selain investasi pasar saham tidak memiliki pasar sekunder yang mengakibatkan besarnya biaya untuk keluar lebih awal. Tidak likuidnya investasi tersebut dapat menyebabkan kerugian pada bank (Rianto, 2013: 260).

\section{Pengelolaan Manajemen Risiko}

Manajemen risiko termasuk komponen utama bagi bank yang mana dia harus melindungi bank dari krisis yang tiba tiba terjadi. Dalam melaksanakan tugasnya manajemen risiko perlu melakukan beberapa langkah dalam mekanisme pengelolaanya di antaranya:

1. Identifikasi risiko. Identifikasi risiko ini dilakukan dengan cara mengidentifikasi atau menyelidiki kemungkinan terjadinya risiko pada bank tersebut. Mengidentifikasi ini bertujuan untuk mengetahui 
keadaan yang akan dihadapi oleh bank seperti dalam aspek social, hukum, ekonomi dan lainnya.

2. Analisis risiko yaitu dengan mengukur risiko dengan mengevaluasi sumber data yang akan di ukur dalam risiko setelah itu penyempurnan terhadap sisitem penukuran risiko yang kemungkinan terjadi perubahan data.

3. Evaluasi risiko dilakukan dengan mengevaluasi exposure risikolalu penyempurnaan risiko apabila terjadi perubahan data.

4. Pengendalian risiko. Mengelola risiko yang bersifat membahayakan yang bisa membahaya kan bank tersebut.

\section{METODE PENELITIAN}

Untuk metode yang kami gunakan yakni metode kuantitatif dan berasal dari data annual report Bank Pembangunnan Daerah Jawa Barat dan Bank Banten Tbk. yang terdaftar di Bursa Efek Indonesi (BEI) terdiri dari laporan keungan neraca, laporan laba rugi, dan juga laporan perubahan modal selama periode 2018 sampai 2019. Untuk nantinya akan kami analisis data perhitungan terkait beberapa resiko yang kemungkinan terjadi pada bank tersebut.

\section{HASIL DAN PEMBAHASAN}

\section{Risiko kredit}

Tabel Kredit yang Diberikan Table of Loans

\begin{tabular}{|c|c|c|c|c|c|}
\hline \multirow{2}{*}{ Uraian } & \multirow{2}{*}{ Description } & \multirow{2}{*}{2019} & \multirow{2}{*}{2018} & \multicolumn{2}{|c|}{$\begin{array}{l}\text { Pertumbuhan } \\
\text { Growth }\end{array}$} \\
\hline & & & & $\begin{array}{l}\mathrm{Rp} \\
\text { IDR }\end{array}$ & $\%$ \\
\hline (1) & (1) & (2) & (3) & $(4)=(2)-(3)$ & $(5)=(4) /(3)$ \\
\hline Pihak berelasi & Related parties & & & & \\
\hline Rupiah & Indonesian IDR & 371592 & 156,432 & 215,160 & $137.54 \%$ \\
\hline
\end{tabular}

Tabel Pertumbuhan Kredit Konsumer selama 5 (lima) Tahun Terakhir Table of Consumer Credit Growth for the Last 5 (five) Years Portfolio

\begin{tabular}{|c|c|c|c|c|c|c|c|c|}
\hline \multirow{4}{*}{ Tahun } & \multicolumn{6}{|c|}{ Portfolio } & \multicolumn{2}{|c|}{ Non Perfoming Loan (NPL) } \\
\hline & \multicolumn{3}{|c|}{ Outstonding } & \multicolumn{3}{|c|}{ Number of Account (NoA) } & \multirow[b]{2}{*}{ Absolut } & \multirow{2}{*}{$\begin{array}{l}\text { Persentase } \\
\text { Percentage }\end{array}$} \\
\hline & Nominal & $\begin{array}{c}\text { Pertumbuhan ( } \mathrm{YoY} \text { ) } \\
\text { Growth }(\mathrm{YOO}) \\
\end{array}$ & \begin{tabular}{|l|} 
Presentase \\
Percentege \\
\end{tabular} & NoA & $\begin{array}{c}\begin{array}{c}\text { Pertumbuhan (YoV) } \\
\text { Growth }(\mathrm{NON})\end{array} \\
\end{array}$ & \begin{tabular}{|l|} 
Presentase \\
Percentage \\
\end{tabular} & & \\
\hline & (Rp) & (Rp) & (B) & (Account) & (Account) & (W) & (Rp) & (4) \\
\hline 2019 & $56,962,542,669,885$ & $4,806,358,873,725$ & $9.38 \%$ & 453,747 & 18,969 & $436 \%$ & $78,964,476,347$ & $0.14 \%$ \\
\hline 2018 & $52,076,183,796,160$ & $4,4282,631,994,471$ & $9.42 \%$ & 43478 & 22,129 & $5.36 \%$ & $94,581,962,097$ & $0.18 \%$ \\
\hline 2017 & $47,593,551,801,609$ & $28800,143,850,944$ & 644t & 412,649 & 19,366 & 4924 & $117,640,972,537$ & $0.25 \%$ \\
\hline 2016 & $44713,407,950,76$ & $6,024,240,442,701$ & $1557 \%$ & 399,283 & 28,457 & $7.80 \%$ & $31,198,430,965$ & $007 \%$ \\
\hline 2015 & $38,609,167,508,044$ & $4,726,183,285,743$ & $1392 \%$ & 364826 & 14382 & $410 \%$ & $32,548962,138$ & $000 \%$ \\
\hline Rata-Rata & & $4,599,911,689,517$ & $10.95 \%$ & & 20,661 & $5.31 \%$ & & \\
\hline
\end{tabular}




\section{Risiko pasar}

Tabel Pengungkapan Risiko Pasar Menggunakan Metode Standar

\begin{tabular}{|c|c|c|c|c|c|c|c|c|c|c|}
\hline \multirow{3}{*}{ No } & \multirow{3}{*}{ Keterangan } & \multirow{3}{*}{ Description } & \multicolumn{4}{|c|}{2019} & \multicolumn{4}{|c|}{2018} \\
\hline & & & \multicolumn{2}{|c|}{ bank bjb } & \multicolumn{2}{|c|}{$\begin{array}{l}\text { Konsolidasi } \\
\text { Consolidation }\end{array}$} & \multicolumn{2}{|c|}{ bank bjb } & \multicolumn{2}{|c|}{$\begin{array}{l}\text { Konsolidasi } \\
\text { Consolidation }\end{array}$} \\
\hline & & & $\begin{array}{l}\text { Beban } \\
\text { Modal } \\
\text { Copital } \\
\text { Expenses }\end{array}$ & $\begin{array}{l}\text { ATMR } \\
\text { RWA }\end{array}$ & $\begin{array}{l}\text { Beban } \\
\text { Modal } \\
\text { Capital } \\
\text { Expenses }\end{array}$ & $\begin{array}{l}\text { ATMR } \\
\text { RWA }\end{array}$ & $\begin{array}{c}\text { Beban } \\
\text { Modal } \\
\text { Copital } \\
\text { Expenses }\end{array}$ & $\begin{array}{l}\text { ATMR } \\
\text { RWA }\end{array}$ & $\begin{array}{c}\text { Beban } \\
\text { Modal } \\
\text { Copital } \\
\text { Expenses }\end{array}$ & $\begin{array}{l}\text { ATMR } \\
\text { RWA }\end{array}$ \\
\hline (1) & (2) & (2) & (3) & (4) & (5) & (6) & (7) & (8) & (9) & (10) \\
\hline \multirow[t]{3}{*}{1} & Risiko Suku Bunga & Interest Rate Risk & & & & & & & & \\
\hline & a. Risiko Spesifik & a. Specific Risk & 5,794 & 72,420 & 5,794 & 72,420 & 87,199 & $1,089,986$ & 87,199 & $1,089,986$ \\
\hline & b. Risiko Umum & b. General Risk & - & & - & & - & & - & \\
\hline 2 & Risiko Nilai Tukar & Exchange Rote Risk & 9,954 & 124,425 & 9,954 & 124,425 & 13,983 & 174,784 & 13,983 & 174,784 \\
\hline 3 & Risiko Ekuitas *) & Equity Risk *) & & & & & & & & \\
\hline 4 & Risiko Komoditas *) & Commodity Risk *) & & & & & & & & \\
\hline \multirow[t]{2}{*}{5} & Risiko Option & Option risk & & & & & & & & \\
\hline & Total & Total & 15,748 & 196,845 & 15,748 & 196,845 & 101,182 & $1,264,770$ & 101,182 & $1,264,770$ \\
\hline
\end{tabular}

\section{Risiko operasional}

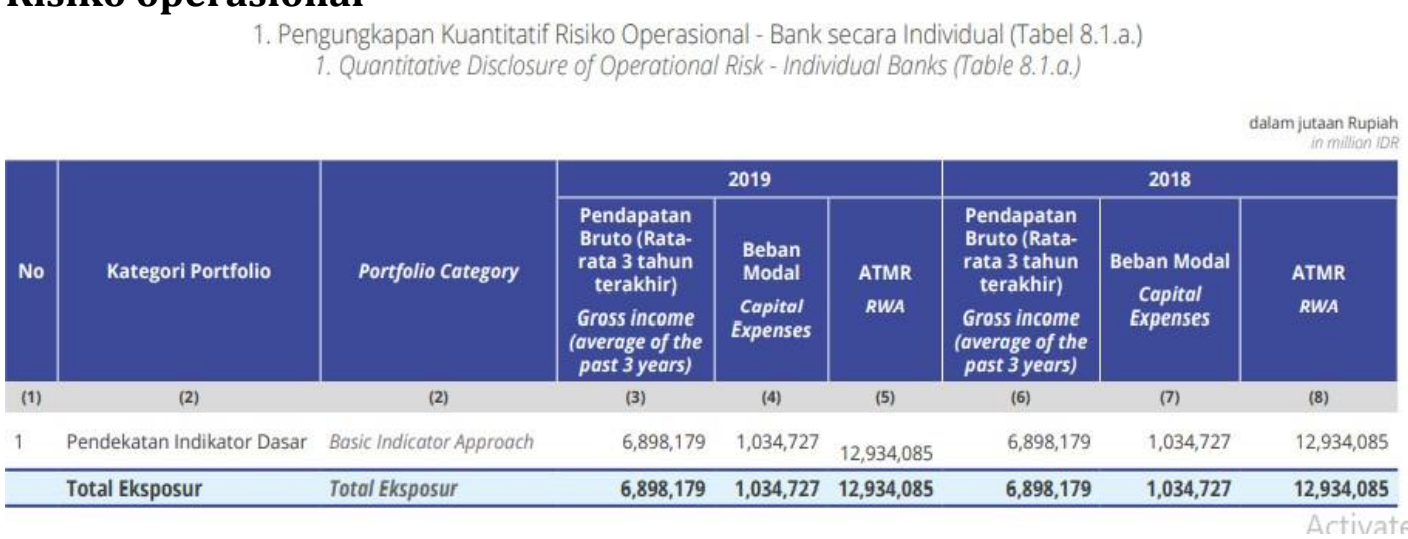

\section{Pengungkapan Kuantitatif Risiko Operasional - Bank secara Konsolidasi dengan Perusahaan Anak (Tabel 8.1.b.) 2. Quantitative Disclosure of Operational Risk - Bank Consolidated with Subsidiaries (Table 8.1.b.)}

\begin{tabular}{|c|c|c|c|c|c|c|c|c|}
\hline & & & & & & & & $\begin{array}{l}\text { Im jutaan Rupiat } \\
\text { in million id }\end{array}$ \\
\hline \multirow[b]{2}{*}{ No } & \multirow[b]{2}{*}{ Kategori Portfolio } & \multirow[b]{2}{*}{ Portfolio Cotegory } & \multicolumn{3}{|c|}{2019} & \multicolumn{3}{|c|}{2018} \\
\hline & & & $\begin{array}{l}\text { Pendapatan } \\
\text { Bruto (Rata. } \\
\text { rata } 3 \text { tahun } \\
\text { terakhir) } \\
\text { Gross income } \\
\text { (average of the } \\
\text { past } 3 \text { years) }\end{array}$ & $\begin{array}{l}\text { Beban } \\
\text { Modal } \\
\text { Copital } \\
\text { Expenses }\end{array}$ & $\begin{array}{l}\text { ATMR } \\
\text { RWA }\end{array}$ & $\begin{array}{c}\text { Pendapatan } \\
\text { Bruto (Rata- } \\
\text { rata } 3 \text { tahun } \\
\text { terakhir) } \\
\text { Gross income } \\
\text { (overage of the } \\
\text { post } 3 \text { years) }\end{array}$ & $\begin{array}{c}\text { Beban Modal } \\
\text { Copital } \\
\text { Expenses }\end{array}$ & $\begin{array}{c}\text { ATMR } \\
\text { RWA }\end{array}$ \\
\hline (1) & (2) & (2) & (3) & (4) & (5) & (6) & (7) & (8) \\
\hline \multirow[t]{2}{*}{1} & Pendekatan Indikator Dasar & Basic Indicator Approach & $6,898,179$ & $1,034,727$ & $12,934,085$ & $6,898,179$ & $1,034,727$ & $12,934,085$ \\
\hline & Total Eksposur & Total Eksposur & $6,898,179$ & $1,034,727$ & $12,934,085$ & $6,898,179$ & $1,034,727$ & $12,934,085$ \\
\hline
\end{tabular}




\section{Risiko likuiditas}

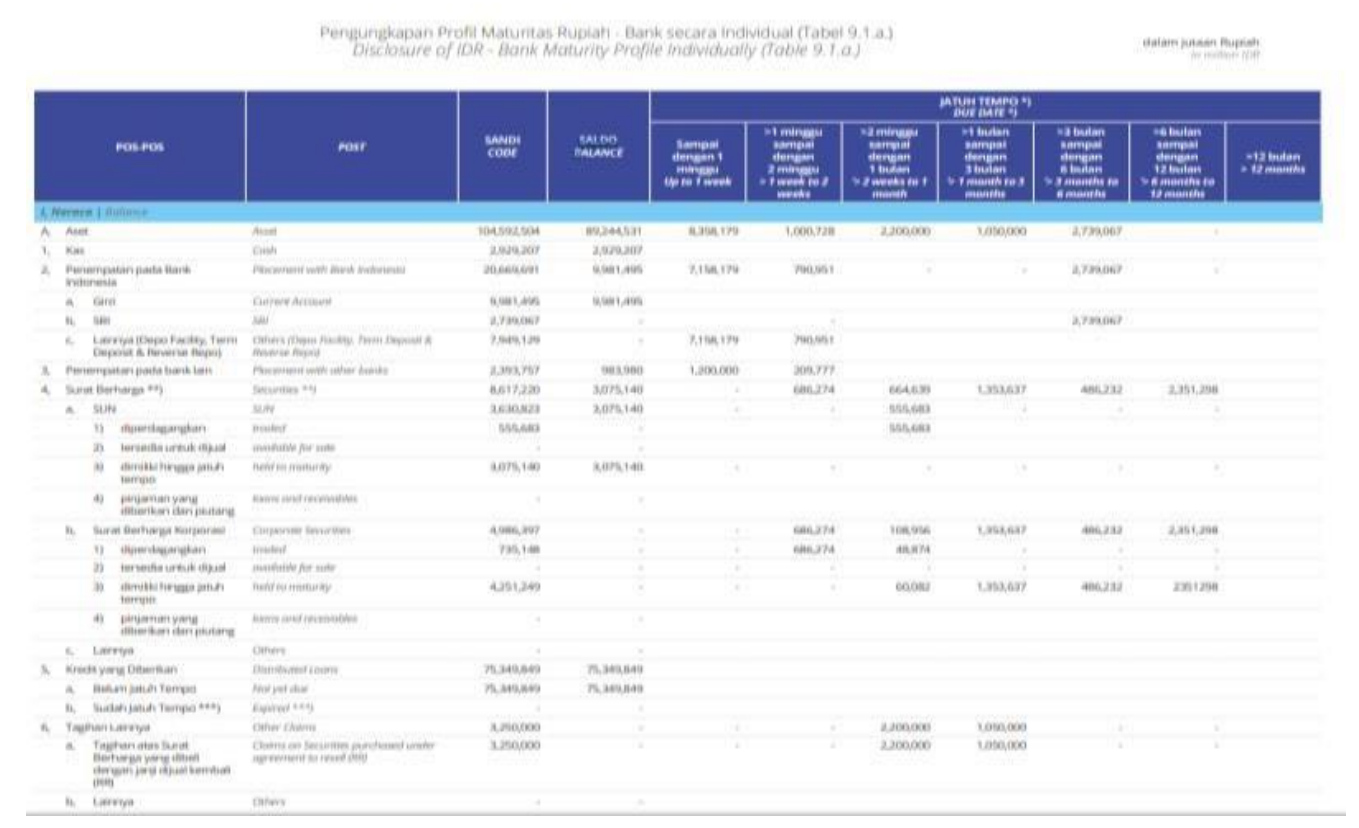

\section{Risiko hukum}

Risiko hokum bersumber pada operasional, ketidakpastiaan hukum, kelalaian penerapan hukum, perjanjian dengan pihak ketiga serta masalah yurisdiksi antar negara. Bank BJB memiliki pihak, dimana pihak tersebut berkepentingan mengenai dengan risiko hukum. Pihak tersebut terdiri atas Dewan Komisaris, Direksi dan seluruh karyawan bank, ketiga pihak ini bertanggungjawab dalam pengelolaan risiko hokum.

\section{Risiko reputasi}

Dari pengawasan Aktif Dewan Komisaris Dan Direksi Dewan Komisaris dan Direksi bank BJB selalu memantau efektivitas penerapan Manajemen Risiko Reputasi dari bank sendiri. Pihak Bank BJB selalu memperoleh informasi secara jelas mengenai evaluasi dan penerapan manajemen risiko reputasi, untuk pengelolaan terhadap risiko reputasi sendiri bank BJB telah membentuk unit kerja yaitu Divisi Corporate Secretary, yang berfungsi melakukan pengelolaan terhadap reputasi bank dan mengatur mengenai standar layanan di Kantor Cabang sebagai langkah untuk memitigasi risiko reputasi. sebagai langkah dalam memitigasi risiko pada nasabah.

\section{Risiko strategis}

Risiko Strategis adalah risiko yang diakibatkan dari ketidaktepatan dalam pengambilan keputusan stratejik dan kegagalan dalam mengantisipasi perubahan lingkungan bisnis. Didalam melakukan strategi bisnis sebisa mungkin menyesuaikan tingkat risiko dari bank selain itu bank juga melakukan penyesuaian strategi dari mulai pendek, menengah hingga strategi panjang yang disesuaikan dengan situasi dan kondisi 
perkembangan bisnis internal maupun rencana bisnis bank (RBB) yang eksternal. Di bank bjb diterapakan ditetapkan oleh Direksi.

\section{Risiko kepatuhan}

\begin{tabular}{|c|c|c|c|c|c|c|}
\hline Uraian & 2019 & 2018 & 2017 & 2016 & 2015 & Description \\
\hline KEPATUHAN & & & & \multicolumn{3}{|r|}{ COMPLIANCE } \\
\hline Persentase Pelanggaran BMPK & & & & \multicolumn{3}{|r|}{ Percentage of LLL Violation } \\
\hline Pihak Terkait & - & - & - & - & . & Related Party \\
\hline Pihak Tidak Terkait & - & - & - & - & - & Non-Related Parties \\
\hline Persentase Pelampauan BMPK & & & & \multicolumn{3}{|r|}{ Percentage of Violation to BMPK } \\
\hline Pihak Terkait & - & - & - & - & - & Related Party \\
\hline Pihak Tidak T erkait & - & - & - & - & - & Non-Related Parties \\
\hline GWM Utama Rupiah & 6.52 & 7.34 & 6.67 & 7.92 & 8.10 & Primary GWM - Rupiah \\
\hline GWM Valuta Asing & 8.50 & 8.66 & 9.39 & 11.33 & 8.38 & Foreign Currency GWM \\
\hline $\begin{array}{l}\text { Posisi Devisa Neto (PDN) secara } \\
\text { keseluruhan }\end{array}$ & 1.11 & 1.72 & 0.47 & 0.58 & 0.47 & Net Open Position (NOP) as a whole \\
\hline
\end{tabular}

\section{Risiko imbal hasil}

\section{Tabel Beban Bunga dan Bagi Hasil Syariah Table of Interest Expense and Sharia Profit:Sharing}

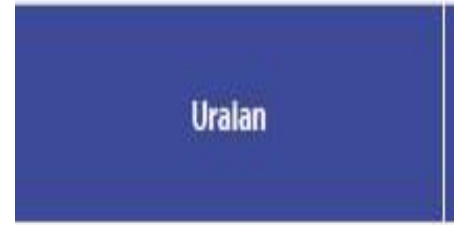

(1)

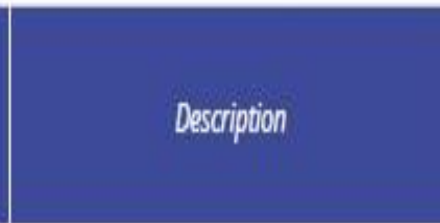

(1)

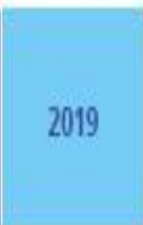

(2)

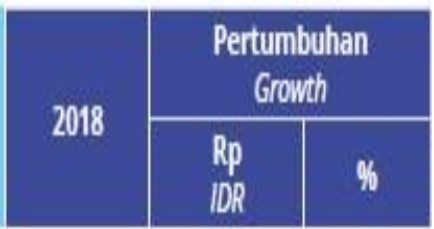

(3) $\quad(4)=(2)-(3) \quad(5)=(4) /(3)$

\section{$\begin{array}{lllll}\text { Beban bunqa dan baqi hasil syariah } \quad \text { Interest Expense ond Shorio Proft:-Shoring } & (6,008,924) & (5,415,178) & (593.746) & 10,96 \%\end{array}$}

\section{Risiko investasi}

Tabel Arus Kas Dari Aktivitas Investasi Table of Cash Flow from Investment Activities

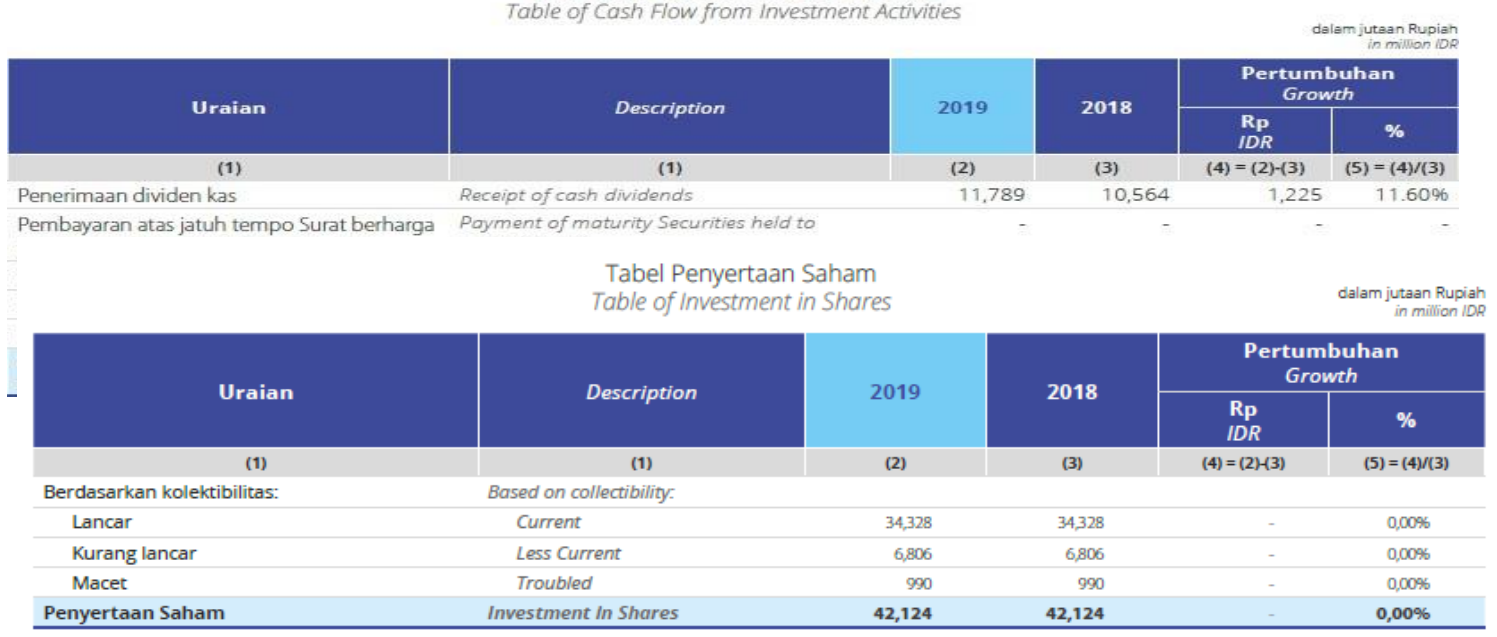


Laporan rasio keuangan Quartal I tahun 2020 Bank BJB

\begin{tabular}{|c|c|c|c|}
\hline & RASIO KINERJA & 2020 & 2019 \\
\hline 1 & $\begin{array}{l}\text { Kewvajiban } \\
\text { (KPMM) }\end{array}$ penyediaan modal minimum & $15,48 \%$ & $15,95 \%$ \\
\hline 2 & $\begin{array}{l}\text { Aset produktif bermasalah dan asset non } \\
\text { produkti dan asset non produktif }\end{array}$ & $3,42 \%$ & $3,18 \%$ \\
\hline 3 & $\begin{array}{l}\text { Total Asset produktif bermasalah terhadap } \\
\text { total asset produktif }\end{array}$ & $3,38 \%$ & $3,70 \%$ \\
\hline 4 & $\begin{array}{l}\text { Cadangan kerugian penurunan nilai (CKPN) } \\
\text { asset keuangan terhadap asset produktif }\end{array}$ & $2,40 \%$ & $2.55 \%$ \\
\hline 5 & NPF Gross & $3,90 \%$ & $4,49 \%$ \\
\hline 6 & NPF Net & $1,35 \%$ & $1,80 \%$ \\
\hline 7 & Return on asset (ROA) & $0,47 \%$ & $0,51 \%$ \\
\hline $\begin{array}{l}8 \\
9\end{array}$ & $\begin{array}{l}\text { Return on equity (ROE) } \\
\text { Net imbalan (NI) }\end{array}$ & $\begin{array}{l}3,90 \% \\
5,47 \%\end{array}$ & $\begin{array}{l}3,87 \% \\
6,27 \%\end{array}$ \\
\hline 10 & Net operating margin (NOM) & $0,40 \%$ & $0,50 \%$ \\
\hline 11 & $\begin{array}{l}\text { Biaya operasional terhadap pendapatan } \\
\text { operasional (BOPO) }\end{array}$ & $95,16 \%$ & $95,04 \%$ \\
\hline 12 & $\begin{array}{l}\text { Pembiayaan bagi hasil terhadap total } \\
\text { pembiayaan }\end{array}$ & $30=40 \%$ & $29,28 \%$ \\
\hline 13 & Financing to deposit ratio (FDR) & $94,58 \%$ & $93,83 \%$ \\
\hline
\end{tabular}

Laporan rasio keuangan Quartal I tahun 2020 Bank BJB

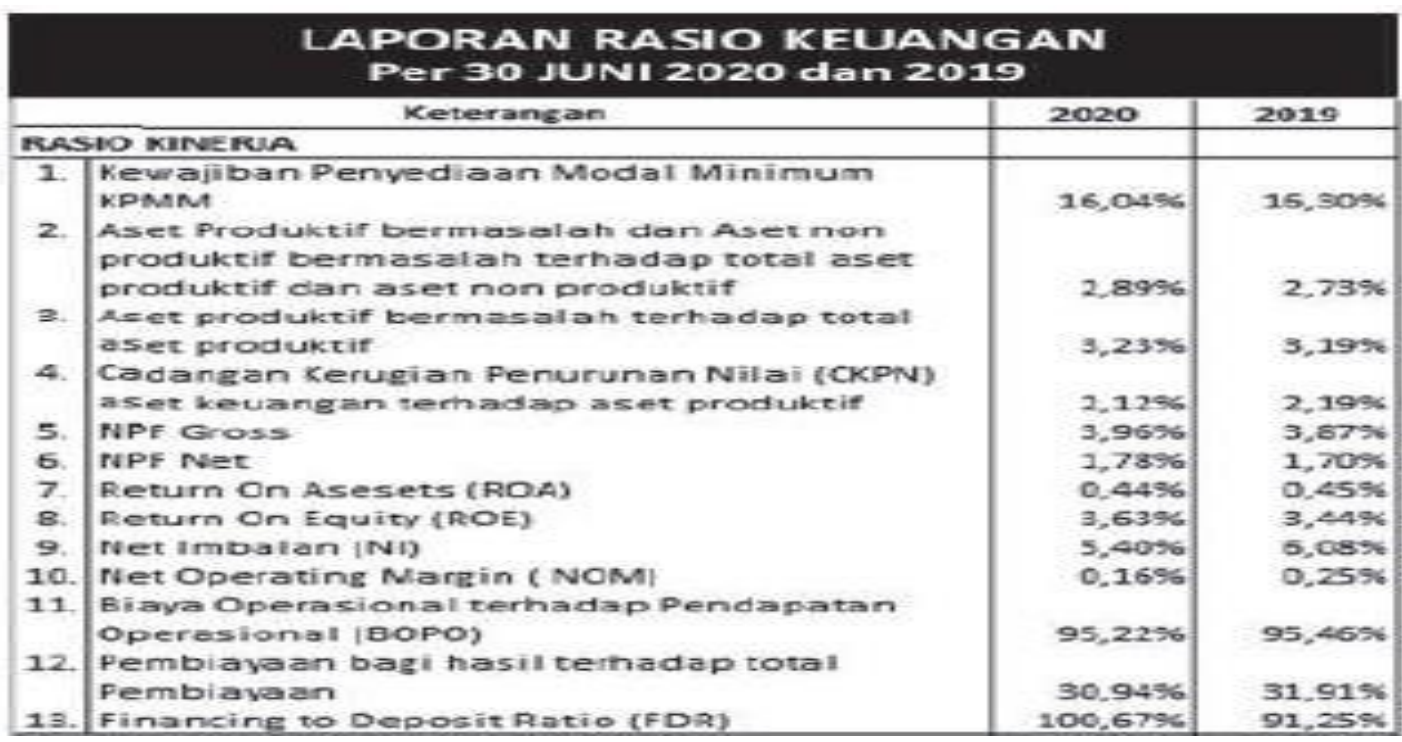

\section{Pembahasan}

\section{Risiko Kredit}

Dari data yang diperoleh, dapat dikatakan bahwa resiko yang di hadapi bank tersebut meningkat yang semula pada 2018 sebesar Rp75.349.849 juta meningkat sebanyak $8,68 \%$ dan pada tahun 2019 menjadi Rp81.887.246 juta hal ini akan berdampak bagi bank karena semakin besar resiko yang di hadapi maka semakin ketat pula dalam memanajemen resikoyang ada.

Dalam hal ini resiko kredit pembiayaan yang besar dikarenakan adanya kendala dalm pihak eksternal yakni pihak nasabah yang tidak mampu membayar kewajibanya saat jatuh tempo. Sehingga resiko kembalinya dana yang di salurkan pun makin besar.Untuk pengklasifikasian npl belum di jelaskan dalam laporan terakit 114 | Manajemen Risiko Pada Bank Pembangunan Daerah Jawa Barat Dan Banten Tbk 
jenis kredit yang di alami pihak bank.

\section{Risiko Pasar}

Dari data yang ada dapat di analisi bahwa dari tahun 2018 ke 2019 resiko pasar pada bank bjb ini mengalami penurunan.Hal ini bisa terjadi karena strategi pengelolaan risiko pasar yang dilakukan bank bjb adalah mencakup sistem dan prosedur dengan menggunakan teknik Mark To Market,Value at Risk (VaR), Stress Testing, Repricing Gap \& Duration Gap Model atau metoda lain yang sesuai untuk mendapatkan nilai wajar eksposur secara berkala, sekaligus merupakan platform yang tepat untuk menilai posisi risiko. Untuk penjenisan resiiko sesuai yang di kemukakan oleh Kasmir yaituGeneral general market risk dan spesific marketrisk. Disini pihak bank menggunakan spesififmarketrisk sebesar 1.089989 pada 2018 menurun sebesar 72.420 pada 2019 karena adanya berbagai strategi yang diterapkan sehingga mampu meminialisir segala resiko yang ada.

\section{Risiko operasional}

Merupakan resiko akibat tidak berfungsinya proses internalbaik kesalahan prosedur mapun kesalah manusianya.Dari data yang ada, bank pembangunan ini mengelami kestabilan di lihat dari pendapatan bruto yang tetap sama dari tahun 2018 menuju 2019 hal ini di karenakan bank bjb mampu mengelola setiap lini perusahaan atau yang biasa di sebut dengan Operational risk management. Disisi lain, bank memiliki unit kerja independen antara lain bankwide yaitu Grup Risiko Operasional yang berada dibawah komando Divisi Manajemen Risiko. Unit ini memiliki fungsi sebagaipenetapan standard dan kebijakan pengelolaan risiko operasional, dan berhubungan serta berkoordnasi dengan seluruh unit bisnis dan supporting unit untuk memastikan langkah mitigasi yang dilakukan telah cukup dan memadai untuk mencegah potensi risiko operasional.

\section{Risiko likuiditas}

Yakni kemampuan bank untuk membayarkan kewajiban jangka panjang maupun jangka pendek kepada pihak nasabah atau lembaga lainya. Dalam hal ini likuiditas dapat di lihat dari data kewajiban jangka pendek pada data yang sudah kami dapatkan dari annual report untuk total kewajibanya sebesar 101.768.387 dan untuk kewajiban jangka pendek rentang waktu $>1$ minggu yang dapat di bayarkan bank tersebut kepada nasabah sebesar 42.642.820 sehingga dapat di ketahui bahwa bank BJB ini kategori likuid karena sudah mampu memenuhi 43\% dari kewajiban jangka pendeknya.

\section{Risiko hukum}

Bank BJB dalam pelaksanaan pengelolaan risiko hukum bank telah memiliki unit kerja khusus yang menangani permasalahan di bidang hukum yang terdiri dari bagian litigasi dan non litigasi. Di samping itu Bank memiliki kebijakan dan pedoman Manajemen risiko hokum. Selain itu 
bank bjb memiliki standarlisasi dokumen hokum bagi produk dan layanan bank dan melakukan review sesuai dengan perkembnagan bisnis bank secara berkala, disamping itu bank bjb melakukan kajian risiko hukum disetiap produk dan aktivitas baru sebagai langkah untuk memitigasi risiko hukum. Melakukan identifikasi, pengukuran, pemantauan dan pengendalian atas risiko hukum oleh Divisi Hukum termasuk dalam kecukupan proses penerapan manajemen risiko.

\section{Risiko reputasi}

Untuk pengelolaan terhadap risiko reputasi sendiri bank BJB telah membentuk unit kerja yaitu Divisi Corporate Secretary. Bank BJB memiliki kebijakan dan pedoman mengenai Manajemen risiko reputasi secara berkala dilakukan pembaharuan dan evaluasi atas kebijakan dan pedoman manajemen risiko bank tersebut. Bank bjb memiliki proses Identifikasi, Pengukuran, Dan Pengendalian Risiko, Serta Sistem Informasi Manajemen Risiko Dalam kecukupan penerapan proses manajemen risiko. Dalam proses pengendaliannya, bank memiliki call center serta mengadakan coaching clinic bagi karyawan dengan memberikan training mengenai standar layanan.Bank memiliki unit kerja khusus dalam proses pelaksanaan manajemen risiko reputasi yang mencakup pengawasan atas pemberitaan negatif dan keluhan yang berdampak pada reputasi bank dan kegiatan pengendalian yang dipantau oleh satuan kerja manajemen risiko.

\section{Risiko strategi}

Di bank bjb diterapakan rencana bisnis bank (RBB) yang ditetapkan oleh Direksi.Seluruh unit bisnis/unit pendukung bertanggung jawab dalam membantu Direksi menyusun perencanaan stratejik dan mengimplementasikan strategi yang telah ditetapkan secara efektif. Dalam penerapan proses manajemen risiko sendiri bank bjb melakukan identifikasi, pengukuran, dan pengendalian atas risiko stratejik. Upaya yang dapat diterapkan risiko stratejik dengan melakukan analisis dalam pencapaian kinerja bank, melakukan business review atas pencapaian kinerja bisnis secara berkala.

\section{Risiko kepatuhan}

Pada bank bjb tidak melakukan ketidakpatuhan pada hukum perundang undangan dan ketentuan yang berlaku. dilihat dalam tabel yakni presentase pelanggaran BMPK dari pihak terkait dan pihak tidak terkait itu sejak tahun 2015 sampai 2019 itu tidak ada (nihil). Sedangkan pada presentase pelampauan BMPK dari pihak terkait dan pihak tidak terkait itu juga nol atau tidak ada pelanggaran yang dilakukan oleh BJB.

Sedangkan giro wajib minimum (GWM) utama rupiah yang di tetapkkan oleh BI sebesar 5\% dari jumlah total dana pihak ketiga (DPK) itu tidak terjadi ketidakpatuhan dimana bjb selalu melakukan pembayaran wajib tersebut. Dari data tersebut di ketahui bahwa pada tahun 2019 DPK pada bjb

116 | Manajemen Risiko Pada Bank Pembangunan Daerah Jawa Barat Dan Banten Tbk 
menurun dari sebelumnya dimana terlihat GWM yang di bayar juga menurun di banding tahun lalu. Sedangkan GWM valuta asing itu sebesar 3\% dari dana pihak ketiga (DPK). Itu juga tidak terjadi ketidakpatuhan dimana bjb mematuhi perundang-undangan dan ketentuan yang di tetapkan oleh BI.

Jadi, bank bjb hukum mematuhi perundang-undangan dan ketentuan hukum yang berlaku karena sejak tahun 2015 sampai 2019 tidak ada presentase melakukan pelanggaran BMPK. Bjb selalu melakukan pembayaran wajib yang ditetapkan oleh BI sebesar 5\% dari jumlah DPK.Pada tahun 2019 DPK pada bjb penurun, dibandingkan dengan tahun lalu.GMW valuta asing pada bjb mematuhi peraturan perundanga-undangan dan ketentuan yang ditetapkan dengan besar 3\% dari DPK.

\section{Risiko imbal hasil}

Pada bank bjb juga memberikan imbal hasil (bunga) pada produk yang diberikan seperti halnya giro, tabungan, dan deposito. Beban bunga dan bagi hasil syariah tahun 2019 mencapai Rp6.008.924 meningkat 10,96\% dibandingkan tahun 2018 yang mencapai $(R p 5,415,178)$ juta. Peningkatan tersebut karena adanya penambahan pada pos simpanan nasabah syariah baik yang ditempatkan oleh pihak ketiga ataupun bank lain pada tahun 2019.

Jadi pada bankBJB telah mengalami peningkatan imbal hasil dan resiko yang di dapatkan nasabah itu minus dimana bank bjb memberikan imbal hasil pada nasabah dan mengalami peningkatan dari tahun sebelumnya.

\section{Risiko investasi}

Risiko investasi adalah risiko unik yang dihadapi bank islam. Dari tabel berikut kita tahu bahwa investasi saham pada BJB masuk dalam kategori L (Lancar) Pada tahun 2019 investasi saham lancar 34,328 kurang lancar 6,806 dan macet 900, serta total penyertaan saham pada 2019 senilai 42,124.

Arus kas neto digunakan untuk aktivivitas investasi tahun 2019 mencapai (Rp241.006) juta meningkat 9,38\% dibandingkan tahun 2018 yang mencapai (Rp220,340) juta. Peningkatan tersebut karena pembelian aset tetap.Risiko investasi berpotensi muncul saat bank menyalurkan pembiayaan berbasis bagi hahasildebitur.Jadi risiko investasi disini bukan mengarah pada risiko akibat investasi bank pada asset keuangan.

Ketentuan penyediaan modal minimum (KPMM)/CAR (Capital Adequacy Ratio)

Perhitungan KPMM yaitu ;

$$
\mathrm{KPMM}=\underline{\text { MODAL INTI }}
$$

ATMR

KPMM itu di hitung dengan rumus modal inti dimana modal inti di dapat dari seluruh modal yang ada dalam perusahaan baik dari pemilik perusahaan atau investor dan di bandingkan dengan aset tertimbang menurut resiko yakni perhitungan aset berdasar- 
kan profil resikonya, sedangkan aset yang tidak beresko tidak di perhitungkan dan aset beresiko semakin di perhitungkan. Intinya setiap aset memilki bobot resiko yang berbeda beda antara modal inti ataupun ATMR itu sendiri. Berikut ketentuan bobot yang di tetapkan :

1. $>14 \%$ : perusahaan dalam kategori sehat dan aman

2. $8-14 \%$ : perusahaan dikategorikan warning

3. $<8 \%$ : tidak sehat,

4. Semakin beresiko bank, minimum CAR semakin tinggi.

KPPM pada quartal I pada tahun 2020 bank BJB ditentukan dengan rumus:

$$
\begin{aligned}
\mathrm{KPPM} & =\frac{\text { Modal Inti }}{\text { ATMR }} \\
& =\frac{701.074}{4.629 .052} \times 100 \% \\
& =15,48 \%
\end{aligned}
$$

KPPM pada quartal II pada tahun 2020 bank BJB ditentukan dengan rumus:

$$
\begin{aligned}
\mathrm{KPPM} & =\frac{\text { Modal Inti }}{\text { ATMR }} \\
& =\frac{702.283}{4.377 .896} \times 100 \% \\
& =16,4 \%
\end{aligned}
$$

Jadi pada quartal I tahun 2020 per 30 maret KPMM (ketentuan penyedian modal minimum) pada bank BJB berjumlah 15,48\% yang di kategorikan perusahaan tersebut dalam keadaan sehat dan aman (Lancar). Sebenarnya KPMM Bank BJB tersebut mengalami penurunan sekitar $2 \%$ dibanding tahun sebelumnya. Kemungkinan karena di akibatkan terkena dampak covod-19 yang melanda Indonesia.Sedangkan KPMM quartal II per juni 2020 sebesar $16,4 \%$ maka dari itu bank ini termasuk bank yang sehat dan aman. Jadi KPMM Bank BJB terdapat peningkatan dari quartal I ke quartal II dengan naik $1 \%$ kemungkinan karena perbaikan kinerja keuangan usai covid-19.

\section{Aset bermasalah}

Aset bermasalah ini adalah membandingkan aset produktif bermasalah dan aset non produktif bermasalah terhadap total aset produktif dan total aset non produktif. Dari OJK sendiri itu tidak memberikan ketentuan berapa besar presentasenya untuk itu perlu di bandingkan dengan bank lain. Dengan ketentuan:

1. Semakin besar menujukkan semakin banyaknya porsi aset yang bermasalah

2. Semain kecil menunjukkan bahwa perusahaan (bank) semakin bagus.

Jadi pada quartal 1 bank BJB memiliki aset bermasalah sebesar $3,42 \%$ yang bisa di kategorkan termasuk kurang sehat (kurang lancar) karena semakin besar asset bermasalah pada bank maka menunjukkan semakin banyak porsi asset bermasalah pada bank BJB tersebut. Asset bank bermasalah BJB mengalami kenaikan di banding tahun sebelumnya di karenkan juga terkena dampak covid -19 yang melanda pada bulan bulan pertama (quartal 1).Sedangkan Pada Bank BJB quartal II, aset produktif bermasalah dan aset non-produktif bermasalah terhadap total aset produktif dan aset non-produktif menunjukkan presentase 
sebesar 2,89\%. Jadi dapat disimpulkan jika aset yang bermasalah presesntase sedikit makan bank tersebut semakin baik.Setelah mengalami peningkatan pada triwulan pertama asset bermasalah pada bank BJB ini kembali turun pada quartal II per bulan juni 2020 sebesar 1\%. untuk mengatasinya dengan cara menjual/melelang asset bermasalah. Dalam hal ini karena bank BJB memiliki asset bermasalah yang tidak sedikit maka lebih baik dijual.

\section{Aset produktif bermasalah}

Asset produktifbermasalah ini membandingkan asset produktif bermasalah terhadap total asset produktif. Bedanya dengan yang asset bermasalah yakni hanya memperhitungkan asset produktifnya saja. Dalam konsepnya aset produktif bermasalah memiliki ketentuan yaitu:

1. Semakin besar maka semakin banyak porsi asset produktif yang bermasalah.

2. Semakin kecil maka semakin baik.

Pada tahun 2020 quartal I bank memilki asset produktif bermasalah sebesar 3,38\% yang artinya bank bisa di katakan lumayan sehat (kurang lancar) dimana semakin besar maka semakin banyak porsi asset produktif yang bermasalah .Sedangkan Pada quatal II, menunjukkan presentase sebesar 3,23\%, jadi dapat disimpulkan bahwa aset produktif bermasalah semakin kecil semakin baik.

Jadi pada asset produktif bermasalah pada BJB ini pada quartal I dibandingkan quartal II menglami penurunan yang sedikit dalam artian bank BJB ini masih memiliki asset produktif bermasalah yang banyak, di bandingkan dengan bank besar lainnya. Jadi untuk mengatasi adanya Aset produktif bermasalah bank BJB harus melakukan CKPN (cadangan kerugian penurunan nilai). Dimana dalam hal ini bank BJB harus memperhitungkan setiap jenis aktiva bank yang masih outstanding dari yang berkualitas lancar hingga macet.

\section{Cadangan kerugian penurunan nilai (CKPN)}

CKPN ini membandingkan CKPN nya dengan asset produktif. Dimana CKPN ini adalah cadangan kerugian penurunan nilai asset asset prodiktif. Cadangan yang dimaksud dari CKPN tersebut adalah cadangan yang di bentuk oleh bank untuk mengantisipasi kemungkinan kerugian akibat penanaman dana dalam asset produktif. Pada OJK sendiri tidak memberikan ketentuan berapa presentasenya, tapi dibandingkan dengan perbankan lain. Tapi ada ketentuan lain yakni :

a. Semakin besar maka ekspetasi kredit macet semakin besar

b. Semakin besar maka membebani keuntungan bank dan menurunkan CAR.

Pada quartal 1 bank BJB tahun 2020 itu sebesar 2,40\% yang artinya bank BJB ini memiliki ekpetasi kredit yang gagal bayar di tahun 2020 ini termasuk kecil, tapi terdapat penurunan bisa di lihat pada tahun sebelumnya. Sedangkan pada quartal II 
tahun 2020 CKPN pada Bank BJB ini menunjukkan presentase 2,12\%. Dimana terdapat penurunan CKPN pada quartal I dan quartal II kemungkinan pembaharuan usai covid-19.

Dari kami sendiri sebenarnya masih bingung kenapa ada penurunan CKPN pada tahun 2020 dibanding 2019 dimana tahun 2020 ini tahun sulitnya untuk perbankan seharusnya mengalami peningkatan seperti bank besar lainnya yang mempunyai CKPN rata rata $3-4 \%$. Kemungkinan karena sedikitnya kredit pada BJB tersebut. Dimana di karenakan covid-19 ekspetasi kredit gagal bayar semakin tinggi.Pada situasi pandemi seperti ini langkah yang dilakukan bank pada umumnya adalah menaikkan cadangan kerugian penurunan nilai ini dengan tujuan untuk menutupi kerugian yang terkena dampak pandemi.

\section{NPL Gross dan NPL Nett (Non Performing Loan)}

Sebelumnya kita harus tahu tentang Kualitas kredit:

1. Lancar: peninjauan bayar tepat waktu

2. Dalam perhatian khusus: peninjauan nunggak 1-90 hari

3. Kredit kurang lancar: peninjauan nunggak 91-120 hari

4. Di ragukan: peninjauan nunggak 121-180 hari

5. Macet: peninjauan nunggak 190 hari Kategori NPL GROSS meliputi : kurang lancar + diragukan + macet, sedangkan NPL NET meliputi : NPL GROSS - CKPN Dengan ketentuan:

1. Semakin besar: semakin beresiko, semakin banyak yang gagal bayar

2. Semakin besar: menurunkan profitabilitas bank

3. NPL gross: $>5 \%$ artinya (warning)

Pada quartal 1 bank BJB Tahun 2020 memiliki NPL Gross sebesar 3,90\% dan NPL Nett sebesar 1,35\% yang artinya bank BJB ini masih di kategorikan aman. Bisa di bandingkan dengan tahun sebelumnya dimana NPF gross meningkat sedangkan NPF net nya menurun.Sedangkan pada quartal II Per juni 2020 menunjukkan presentase sebesar 3,96\% jadi dapat disimpulkan NPF gross bank ini "Aman" sedangkan NPF nett Bank BJB menunjukkan presentase $1,78 \%$ berarti bank ini dinyatakan "Aman". Jadi bila di bandingkan antar quartal I dan quartal II Terdapat peningkatan NPL Gross dan NPL Nett.Jadi jika terjadi peningkatan betambah bank BJB harus melakukan penjualan asset yang bermasalah dan selanjutnya tetap melakuka penagihan pada kredit kredit bemasalah.

ROA (RETURN ON ASSET) DAN ROE (RETURN ON EQUITY)

Return On Asset (ROA)

$\mathrm{RA}=\underline{\text { Laba Sebelum Pajak }}$

Rata-rata total asset

Aset $=$ Liabilities + Equity (Modal

Inti)

Return On Equity (ROE)

$$
\mathrm{RE}=\frac{\text { Laba Sesudah Pajak }}{\text { Rata-rata total ekuitas }}
$$

Equity $=$ Aset - liability

Dengan ketentuan Semakin besar : semakin bagus dan profitable. Return On Asset (ROA) pasti akan kecil 
dibandingkan dengan Return On Equity (ROE) karena memiliki porsi yang besar. Perusahaan dengan Return On Equity (ROE) diatas 15\% biasannya tergolong baik dan sehat.

Dalam bank BJB ditahun 2020 kuartal 1, memilikiReturn On Asset (ROA) sebesar 0,47\% dan Return On Equity (ROE) sebesar 3,90\%. Jadi, dapat disimpulkan bahwa Return On Asset (ROA) sebesar $0,47 \%$ dikatakan kecil karena dibawah 10\% maka dari itu BJB ini tergolong memiliki kinerja keaungan yang buruk (tidak lancar) begitupun dengan Return On Equity (ROE) sebesar390\% yang tergolong tidak baik dan tidak sehat dibawah $15 \%$ dari ratarata perusahaan. Intinya semakin besar maka akan semakin bagus.Sedangkan pada ROA pada Bank BJB pada tahun 2020 kuartal II berada presentase $0,44 \%$ sedangkan ROE pada bank ini menunjukkan presentase 3,63\%. Jadi dapat disimpulkan bahwa Bank BJB Syariah ini kurang profitabel bagi penanam modal dan investor karena presentase ROA pada bank ini sangat sedikit hanya $0,44 \%$. Tetapi dimata masyarakat biasanya hanya memfokuskan pada ROA saja.

Jadi antara quartal I dan quartal II Presentase keduanya tidak jauh bedan dan Bank BJB ini masuk dalam kategori tidak lancar (tidak profitable). Untuk memgatasi masalah ini kami sarankan melakukan pembaharuan kinerja bank tersebut.

\section{Net Interest Margin (NIM)}

NIM (Net interest Margin) adalah rasio yang digunakan untuk menghitung kemampuan perusahaan dalam menghasilkan keuntungan bunga besih pada bank konvesioanal. Tapi dalam bank syariah menjalankan kegiatan operasional nya tidak menggunakan system bunga, karena itu dalam bank syariah penilaian NIM nya menggunakan rasio NOM ( net operting margin) yang merupakan pendapatan penyaluran dana setelah bagi hasil di kurangi dengan beban operasional terhadap rata rata aktiva produktif. Sedangkan NIM itu membandingkan pendapatan bunga bersih dari bank dengan asset produktif bank tersebut. :

NIM = Pendapatan Bunga Bersih Asset Produktif

N.M = (Pendapatan Penyaluran Dana Setelah bagi hasil-beban operasional)

Rata-rata aktiva Produktif

Jadi pendapatan bunga bersih (Pada NIM): pendapatan bunga - beban bunga JadI NIM ini bukan selisih rata rata bunga pinjaman - bunga tabungan melainkan pendapatan bunga bersih (selisih bunga pinjaman -bunga tabungan) di bandingkan dengan asset produktif dari bank tersebut. Dengan ketentuan: Semakin besar: semakin profitable

Jadi pada tahun 2020 quartal 1 bank bjb ini memiliki n0m sebesar $0,40 \%$ yang artinya bank bjb ini memilki profit yang kecil. Dimana jika NOM nya semakin kecil maka profit yang di peroleh bank bjb ini juga kecil. Bisa di lihat juga dalan tabel pada tahun sebelumnya bjb ini 
NOM ny juga rata rata masih di bawah 1 $\%$ malahan di tahun 2020 ini nom nya menurun kemungkinan di karenakan civid-19. Sedangkan Pada bank BJBtahun 2020 kuartal II menunjukkan presentase NOM sebesar 0,16\%. Artinya dapat disimpulkan bahwa bank ini Tidak lancar (tidak profitable). Dimana nominal ini masih sangat kecil dibandingkan dengan bank besar lainnya. Tapi pada quartal I dan kuartal II mengalami penurunan NOM sedikit tapi dalam hal tersebut tidak mengubah bank tersebut di kategorikan tidak lancar/ buruk.

\section{PENUTUP}

Hasil penelitian ini menunjukkan adanya kondisi lancar dan buruk dalam analisis manajemen dan analisis rasio keuangan pada Bank BJB yang terdiri dari analisis KPMM, Non Performing Asset, CKPN, NPF gross, NPF Net, ROA, ROE, NI, NOM, BOPO, dan FDR. Hasil perhitungan secara keseluruhan pada PT. Bank Pembangunan Daerah Jawa Barat dan Banten Tbk, pada periode 2018-2020 mengalami peningkatan dan penurunan setiap tahunnya.

\section{DAFTAR KEPUSTAKAAN}

\section{Buku}

Pandia. 2013. Manajemen Dana dan Kesehatan Bank. Jakarta: Rineka Cipta

Fenny, Lianti. (2010). Tinjauan atas prosedur pengawasan risiko kredit pada Bank BJB Kantor cabang Cianjur

\section{Artikel dalam Jurnal}

Desda, Mia and Yurasti. Analisis Penerapan Manajemen Risiko Kredit dalam Meminimalisir Kredit Bermasalah Pada PT. BPR Swadaya Anak Nagari Bandarejo Simpang Empat Periode 20132018. Journal of MBIA. Vol. 18, No. 1, April 2019.

Kisman, Z. Model For Overcoming Decline in Credit Growth (Case Study of Indonesia with Time Series Data 2012m1-2016m12). Journal of Internet Banking and Commerce. Vol. 22,2017.

Paramitha, Dewi. 2014. Pengaruh Risiko Kredit dan Likuiditas Terhadap Profitabilitas Pada Perusahaan Perbankan Yang Go Public 20102012.E-journal Universitas Pendidikan Ganesha. Vol. 2. Tahun 2014 